\title{
Teaching Metaphor: Engaging Student's Creativity in Writing Class
}

\author{
Muh Saeful Effendi
}

Ahmad Dahlan University, Yogyakarta, Indonesia

\begin{abstract}
This paper discusses one of the ways to improve student's writing skill. Having good competence of grammar is not merely in line with writing competence. Above all, creativity, knowledge and experiences are considered to be very important aspects in process of writing. Thus, incorporating concrete student's experience will help students integrate prior experience and facilitate students to write. By doing so, student can generalize notion of the topic they are going to write. Metaphor shows the way in incorporating student's experiences into vivid and meaningful words. Metaphor is a bridge for the interaction between the student's initial state of mind and course of experiences factor. The way covers gathering student's experiences, formulating metaphorical expression, expressing the meaning, peer review and grammar correction. In conclusion, metaphor gives opportunity for students to optimize their strength and to make use their experiences to write creatively. Metaphor also makes learners focus on the form oflanguage. Furthermore, metaphor helps learners to handle linguistic creativity.
\end{abstract}

Keywords : teaching metaphor, student's creativity, writing skill, language

\section{INTRODUCTION}

Writing foreign language is a hard effort for EFL (English as a Foreign Language) Learners. Besides, it is also a hard effort for teacher to have learners meeting the purpose of writing. Most of teachers believe that writing foreign language leads to the frustrating and difficult for the students. The writer meets some obstacles in teaching the first year students in writing class. Writing English as a foreign language is a new experience for most of the students. Based on their confession, they rarely had writing activity in English subject when they were at Junior or High school. When the writer asked them to write certain topic for only two sentences, they spent more time than the writer expected. The writer found that students are not able to get idea for the given topic. Furthermore, they met difficulty in expressing their idea.

Recent research of metaphor gives new perspective toward how students learn language. Metaphor facilitates students' experience of their life toward the initial state to produce language. Metaphor helps students to identify students' experiences and give specific representation toward their experience.

Through this perspective of metaphor, the writer tries to create instructional activity to give new experience for the students in learning English as a foreign language particularly in writing class. The activities involve gathering student's experiences, formulating metaphorical expression, expressing the meaning, peer review and grammar correction.

\section{METAPHOR}

Commonly, metaphor study in literature focuses on poetry in literature class. This paper focuses on the way to make use metaphor to improve students' creativity in writing class.

Metaphor is simply a word as a comparison toward another word. In another word, this comparison is not merely the same in concept, but it sometimes reveals deeper meaning toward the subject discussion. Metaphor is an effective way of thinking to comprehend certain abstract concept. The mechanism starts from broadening the meaning of the concept by comparing with concrete concept that represents the abstract concept. In the conceptual metaphor the both concepts above have special term namely source domain and target domain. The target domain is the domain that we try to understand through the use of source domain (Kovecses, 2010:4) 
The outstanding statement of Shakespeare "all the world's a stage" is an example of metaphor indicating comparison of two words "world" and "stage". Current theory gives new perspective of metaphor that it is not only a rhetorical ornament but it is a concept of thought representing process of thinking. Cameron (2003:27) states that metaphor can lead our thinking to a discourse event traces of previous uses and of previous discourse event. This process of tracing is the process of mind in interpreting student experiences context and also criticizing their interpretation toward certain context. It is about philosophical meaning that metaphor gives opportunity for logic to sayuntruth that actually has truth. This is like comparing two things that are similar.

Moreover, there are two ways to understand metaphor that is classified by two important relations. First, in relation to individual words, metaphor is a basic process of words formation and words meaning. The concept and meaning are lexicalized or express in words through metaphor. Second, in relation to discourse, metaphor is important because of its functions-explaining, clarifying, describing, expressing, evaluating, and entertaining. There are many reasons why we use metaphors in speech or writing: not least, because there is sometimes no other word to refer to a particular thing. But where we have a choice, we choose metaphors in order to communicate what we think or how we feel about something; to explain what a particular thing is like; to convey a meaning in a more interesting or creative way; or to do all of these. Knowles and Moon (2006:3)

\subsection{Metaphor in Student's Life}

The experiences of the students are the most important part in succeeding the objective of teaching metaphor in creative writing. In their world, metaphor is unconsciously close to them. They often produce metaphorical expression like "matakuliahinimimpiburuk" (this subject is nightmare). This expression does not incidentally come up in their mind without any reflective thinking about their experience. If we go further asking them the meaning of their expression, there are many explanations we will get. Students said "matakuliahinisangatsulitpak" (this subject is very difficult sir), "penjelasandosentidakbisakitafahami" (we cannot understand what the lecturer explain), "banyaktugas yang sulitsetiapminggu" (there are many weekly difficult assignment).

The example above is the real portrait of students' metaphorical expression in their daily life. Student produces language trough mind process. The metaphorical word "nightmare" incorporates student's experience, emotion and also critical thinking toward the word "subject". The word "nightmare" is another experience of student that is chosen to represent the word "subject". It is linguistics creativity that "nightmare" actually has its own definition and criterion. The word "nightmare" is an outside knowledge of the students' mind that is inferential toward the student's inner experiences about the word "subject" (Snaevarr, 2010:13).

The students unconsciously use metaphor in their daily life and the most important is that they use metaphor to explain idea, to describe something even it is without any background concept of metaphor. This is line of phenomenon that leads to the writer assumption that students have basic process in expressing their thought through metaphor

\section{Creative Writing}

The term "creative writing" generally involves creative work in a form of literature: work of fiction, poetry and drama. It is a term for all work that close to the writing in the aforementionedliterarygenres. Current theory gives more elaboration toward creative writing that it is a written expression in which children put down their own ideas, thoughts, feelings and impressions in their own words. Creative writing can be called independent writing meaning that the process and the result of writing are far from imitation. It is about individual work that totally from the personal experience and thought. It is writing that is original. It is sincere, personal expression that is flavoured by the personality of the child' (Chapple in Dawson, 2005: 21-22).

Creative writing has several purposes in relation between writer and reader. Creative writing is the same in some aspects with writing concept. It is based on the reason why people want to express a thought, opinion, fact, and even emotion to others through words. People use creative writing for entertainment. This purpose refers to the characteristic of language in literature. The language is nonscientific expression. People write their thought freely, even using deviation words like figure of thought so reader can enjoy the writing. Another purpose of creative writing is informative. It means that the diction used by the author is words in our everyday life. Even it sometime use analogic expression to convey the author thought and experiences. Creative writing is also often used for persuasive purposes. An author writes for the sake of internalizing thought or opinion toward certain issues or topic to other (May, 2007:113). 
Technically, the term of creative writing is used to refer to activity we engage in. an author is really involved in

\subsection{Metaphor and Creative Writing}

Previous statement of Knowles and Moon become an important starting point to understand the rule of metaphor in writing. Conceptually, metaphor has all packages for process of creative writing. Metaphor provides concrete think to help students develop their imagination toward certain abstract thing. Metaphor helps student in explaining and elaborating their idea. If Aristotle defining world is a stage, then the word "stage" will help student to explain about world related to their experience. Students often watch concert, drama and speech on the stage. Based on those experiences, students can express the idea of world in sentences.

In the context of linguistic, metaphor gives alternative for students to learn foreign language particularly English. Some author, Holme and Cameron give vivid elaboration about language and structure of metaphor. This will be beneficial for student to start their creative writing. In examining spoken data of English metaphor, it is found that verb metaphor is expressed more frequently than the noun type.

Holme, in further discussion gives the term of copula metaphor. It is common in English the copula "be" or "become" often occur in a figurative language such as "you are the Sun", "you become the light for life". Copula metaphors identify the topic as a subject, and a vehicle as a complement. But the topic and vehicle can only rarely be given a grammatical identity in this way, since many metaphorical sentences do not have a topic that can be identified in the lexis (MacCormac in Holme, 2004:59). This copula metaphor is used to show that in metaphor, there are two subjects in a sentence. This term is useful for teacher to teach metaphorical expression particularly figurative language. This is because copula metaphor gives clear example of what figurative means.

In different context of metaphor, verb metaphor also occurs as a part of speech. To understand this term, we can see the example below.

"The flower smiles at the coming bee"

The expression above contains non literal meaning. In fact, flower cannot smile. To understand the meaning of "smile", we should think of the flower is a girl and the coming be is a boy. Although there may be a metaphorical focus on a particular part of speech, in this case a verb, there is no clear idea as to whether the metaphor begins and ends here. There are many interpretations can be drawn toward the metaphorical expression above. For example:

Source domain (the smile of beautiful girl as she meets a handsome boy)

Target domain (the response of flower when a bee is approaching)

In context of writing, metaphor can lead to generate narrative. In writing class, teacher can formulate a metaphorical expression and ask the student to interpret it in the form of narrative. For example, teacher gives a sentence of verb metaphor that close to the students' life:

"The dry leaves miss the rain".

In the writer class of writing, the narrative construction of the students is varying. These are some student's narrative work related to the expression above.

Student 1

"It is a love story. There is a girl has been separated for long period of time with her boyfriend. They cannot meet each other even by phone because her boyfriend works in cruise ship. She loves him very much. She really hopes that she can spend much of her time with him, have dinner together, share experiences, and so on. Every night, she always dreams about him."

Students 2

"The dry leave is a son who studies abroad, long way from home and the rain is his parent at his hometown. The son always wants to meet his parent. He misses walking together with his parent in the park every Sunday morning. He misses their affection and attention." 
Student 3

"It is about a student who lived at boarding house. He run out money and asked his father to send some to him. But the money does not arrive yet. He felt so sad. He needs it to buy food."

Those narratives show that metaphor really touches the students' life. Metaphor can represent their emotion. It makes students focus on the language. They enjoy work with dictionary to find difficult words. And the most important is that students are engaged to be creative in writing. Each example of the students' narrative expression shows different experiences and represent students' ability in writing. Some of them make some mistakes in grammar. Teacher need to give feedback to make sure that learn language

The writer then formulates some activities in writing class in order to make use metaphor to give new experience in writing to the students.

Gathering students' experiences

Teacher needs to analyse specific entry competences of the students related to general topic that are going to give to them. In creative writing, students' experiences are the basic need in writing. For example, when teacher want to give verb metaphor "miss", teacher can rise some questions like "whom you miss now? why do you miss it? etc". by doing so, teacher can identify the students' experiences and at the same time lead them to be involved to the topic.

Formulating metaphorical expression

When students have been engaged in the topic, teacher gives a metaphorical expression to them. Teacher should use the word "miss" as the part of the expression. In utilizing metaphor, there are three alternative ways. First, teacher can find it in a poem, novel or song lyric. Second, teacher can modify the existing one. Third, teacher design a new metaphorical expression.

Expressing the meaning

In metaphor, expressing the meaning means interpretation. For verb metaphor, teacher can engage student to interpret it by writing narrative. For this purpose, teacher needs to remind student about the pattern of narrative by giving some example.

Peer review

Providing feedback toward students' work is very important. One of the ways is peer review. By doing so, teacher gives opportunity to the students to observe their friends' ideas. Then, give them a chance to give response toward their friends' work. Students may ask questions.

\section{Grammar correction}

This step is an important part in teaching foreign language. Teacher takes some students' works for sampling, then appreciates their creativity and finallyleads students focusing on grammar. Correction is needed if teacher found mistakes. Finally ending the class with reading the teacher's work is important. It will give inspiration to the students

\section{Conclusions}

Writing foreign language is complex activity. It requires more motivation and inspiration. Metaphor is sometime fit with the mind process to fulfil students' need of motivation and inspiration. Metaphor gives students courage to express idea through metaphor.

Furthermore, understanding metaphor in language teaching is an important starting point for teacher. Teacher needs to dig deeply the students' experiences to get the initial meaning and finally make use a representative metaphor that lead them to the creativity.

\section{REFERENCES}

[1] Kovecses Zoltan. Metahor A Practical Introduction. New York: Oxford University Press. (2010)

[2] Cameron Lynne. Metaphor in Educational Discourse. New York: Continuum. (2003)

[3] Knowles Murray and Moon Rosamund. Introducing Metaphor. New York: Routledge. (2006)

[4] Snaevarr Stefan. Metaphors, Narratives, Emotions: Their Interplay and Impact. New York: Rodopi Amsterdam. (2010) 
[5] Dawson Paul. Creative Writing and the New Humanities. New York: Routledge. (2005)

[6] May Steve (2007). Doing Creative Writing.New York: Routledge. (2007)

[7] Holme Randal. Mind, Metaphor and Language Learning. New York: Palgrave Macmillan. (2004)

\section{AUTHOR'S BIOGRAPHY}

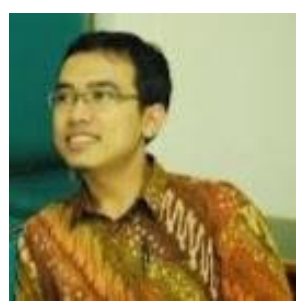

Muh Saeful Effendi, is a lecturer at Ahmad Dahlan University. He currently teaches writing, ICT in ELT, and media development. He works with his students to create media for supporting students in learning English. Metaphor is another thing he use in engaging his students to master English. 